\title{
Characters Comparison in the Aspect of Effective Socialization as Part of the Productive Behaviors on Senior High School Students and Boarding School Students
}

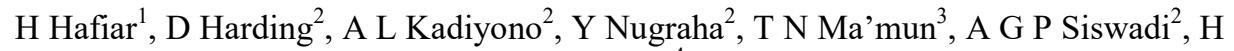 \\ Wibowo $^{4}$ \\ Faculty of Communication Science, Universitas Padjajaran, Indonesia ${ }^{1}$ \\ Faculty of Psychology, Universitas Padjajaran, Indonesia ${ }^{2}$ \\ Faculty of Cultural Science, Universitas Padjajaran, Indonesia ${ }^{3}$ \\ Faculty of Social and Political Science, Universitas Padjajaran, Indonesia ${ }^{4}$ \\ \{hannyhafiar@unpad.ac.id $\left.{ }^{1}\right\}$
}

\begin{abstract}
Boarding school is one of the types of institutions that provide lodging facilities in a particular environment, so boarding school student is possible to have more time and concentrated on the community association to learn Islamic religious-based education in the daily life. On the other hand, the senior high school students, they tend to have a relatively more free time and more diverse community association. These conditions allow the occurrence of character differences, especially in the aspects of effective socialization as one dimension of productive behavior. Therefore, this article is intended at exposing the idiosyncrasies of the characters formed by two different education systems. Research conducted using quantitative descriptive methods using a questionnaire instrument and the observation against senior high school students and boarding school students through the cluster sampling technique. As for the results show the existence of the difference character tendency in between the two objects with the extended respectively as a result of the kind of education system they live, with the following description: fun personal aspect, positive attitude, and enthusiasm of senior high school students tend to be higher than the boarding school students. While the potential to communicate effectively-clearly-open to suggestions/good listener, as well as the ability to work together is higher in boarding school student groups than senior high school students.
\end{abstract}

Keywords: Education System, High School Student, Boarding School Student

\section{Introduction}

Santri is a term that embedded in the students who attended study in Islamic boarding schools. Islamic boarding school's is one of the types of education that offers an integrated system of education with a concentration in the form of academic education of religion, namely Islam. The term boarding gives an overview of this institution that provides facilities for "board" or sleep. This means that the boarding school's students (boarding school) may learn at once settled for a while in the location of the complex he was educated until they graduate studies. This kind of education type has been many offered and has many enthusiasts. 
Many excess values are offered and demand into consideration. One of them is, the kind of education like Islamic boarding school's gives an overview that the children intercommunication during studying is in the religious and maintained environment. This consideration refers to the notion that students of Islamic boarding schools will be administered preoccupied with religious studies intensively and avoid bad association which resulted in many social pathologies caused by juvenile delinquency, because of the scope of his social circle and associates relatively limited to the community in Islamic boarding schools.

This research originated from an inner interest in teenagers characters, which is a part of the formation of the environment, including environmental education. The character position in the social interactions has an important role in the success of the socialization process. Furthermore, effective social skill can be an indicator of productive behavior. This study aims to review closely the character of high school students and boarding school students in connection with effective interaction as part of the productive behavior of adolescents.

Gilmore [1]says that the productive behavior is "Who is making a tangible and significant contribution in his chosen field, who is an imaginative, perceptive, and innovative in his approach to living problem and accomplishment of his own goals (creativity) and who is at the same time both responsible and responsive in his relationship with other. Gilmore[1] emphasizes the positive contribution of a person to the environment where it is located. With constructive action, imaginative, creative individuals in an organization, it expected will be able to improve productivity. That illustrates the private productive potential, perception, and creativity of someone who always wants to donate his ability to benefit themselves and their environment. Thus, productive person is a person who contributed to a significant and means to the surrounding environment, imaginative and innovative in responding to the problems of his life as well as having the understanding (creative) in achieving the goal of his life.

As for the interaction effects, Robert M. Ranftl in[2] states that one of the dimensions of productive behavior is able to hang out with effective, namely Capacity of to establish positive interpersonal relationships, with the following indicators:Fun personality; Communicate with effectively-clearly-open to suggestions - a good listener; Can work together; Demonstrate a positive attitude and enthusiasm.

\section{Method}

This research uses the tools of data collection techniques in the form of a questionnaire which was distributed to students and student boarding schools which institution was selected based on the formula of the cluster. According to Whitney (1960), the descriptive method is fact-finding with the proper interpretation.

A descriptive study of the research problems within the community, as well as the applicable procedures for greeting the public as well as specific situations, including the activities, attitudes about relationships, views, as well as the processes that are taking place and the influence of a phenomenon. As for the other definition is expressed as follows: descriptive research method is a method of research that seeks to describe the object or subject is examined in accordance with what it is [3].

Whereas the definition of cluster random sampling. According to [4], this technique is used when the population does not consist of individuals, but rather are composed of individual groups or clusters. Sampling areas used to determine sample if the object examined or very large data sources, for example, the population of a country, province or district. 


\section{Results and discussion}

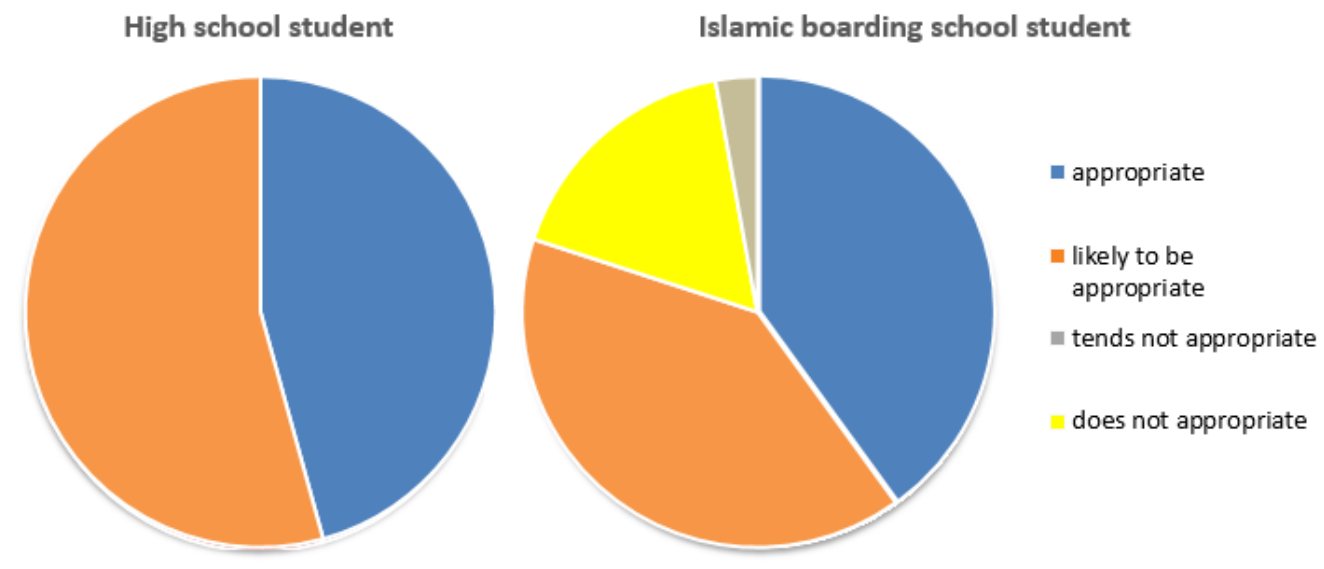

Figure 1. Pleasant Personality.

Based on diagram 1 above, it noted that high school students tend to form themselves into a fun person compared to boarding schools students. It is also supported by the observation that data shows the attitude and behavior of high school students who tend to be freer in filling conversations with comments or actions that are full of humor.

According to Gordon [5]what is meant by personality or personality is defined as a dynamic organization in the individual as the psychologist system that determines how the typical in conformity with or to the environment. About personality traits, temperament, character, habits, which the difference can be described as follows:

- Temperament is the characteristic symptoms of each emotion, as well as easy or not to affected by emotional stimuli, strength, and speed in action, the quality of the power of moods and symptoms, depend on constitutional factors and primarily from descended

- Personality/trait is a generalized system of neurophysics and directed with the ability to deal with the manifold ignite in the same, as well as through the same adaptive guiding and expressive behavior

- Personality or characters are more stable, hereditary or congenital and have a normative nature

- Habit is the same as the trait; the only difference is in circumstances which are matched or responded to the incarnation of the condition. 
High school student

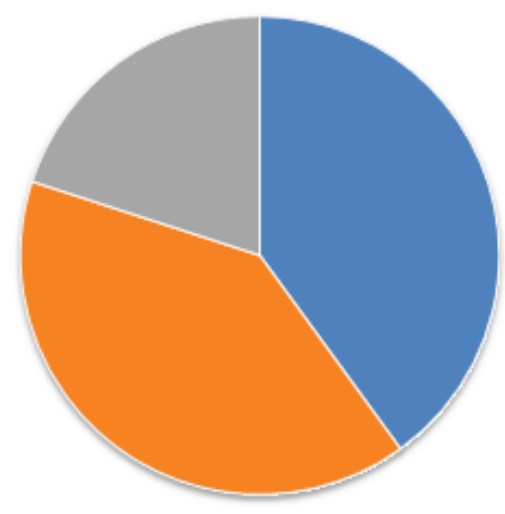

Islamic boarding school student

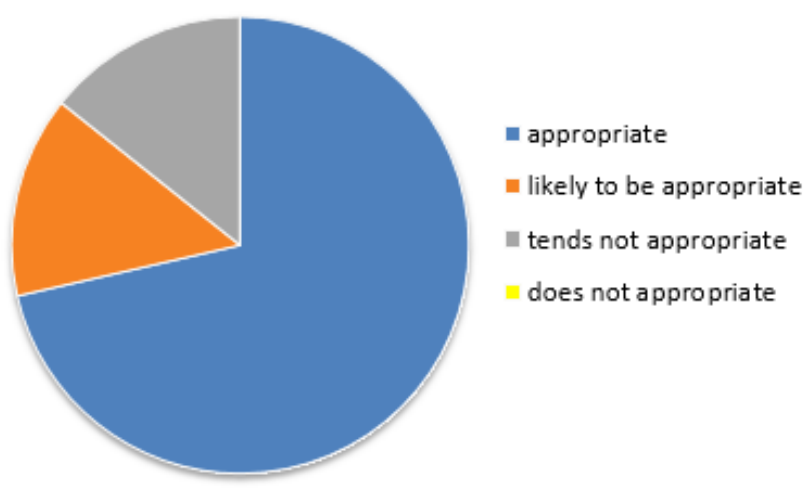

Figure 2. Effective Communication

Refer to Figure 2 can be described the existence of difference socializing about potential results that are effective on the indicator of the ability to communicate effectively. On this indicator is seen that boarding school students have a higher value than high school students. There are things which aspects influenced the results of these findings; one student stated that the ability to communicate is essential to capital preaching, as he acknowledged as follows:

"The truth should be said, but not everyone is able to accept the truth, because sometimes the truth is painful for some people, so we need to create the tricks to convey the truth, minimal conveyed in the polite, gentle, but also to be firm, it means that if it's true stated it's true, otherwise if it's wrong do not hesitate to say that those actions are wrong, and you should be like this, and also tell us what is the argument of the statement, such a thing should be done if you want to preach"

Scrutinize to the given statements; it shows their awareness and understanding of how to communicate effectively in a manner repressive persuasively, but with style. That understanding is expressed based on the presence of a proposition from the Al Qur'an and Hadith.

\section{High school student}

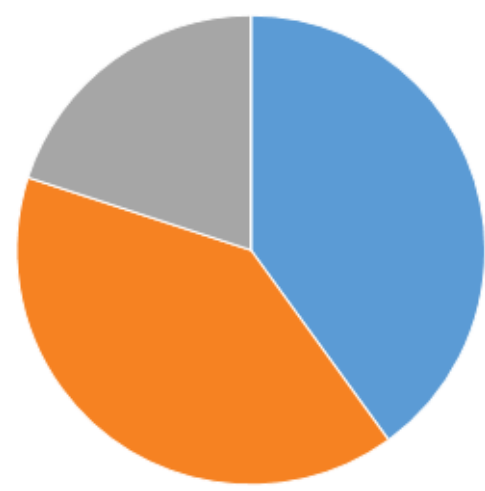

Islamic boarding school student

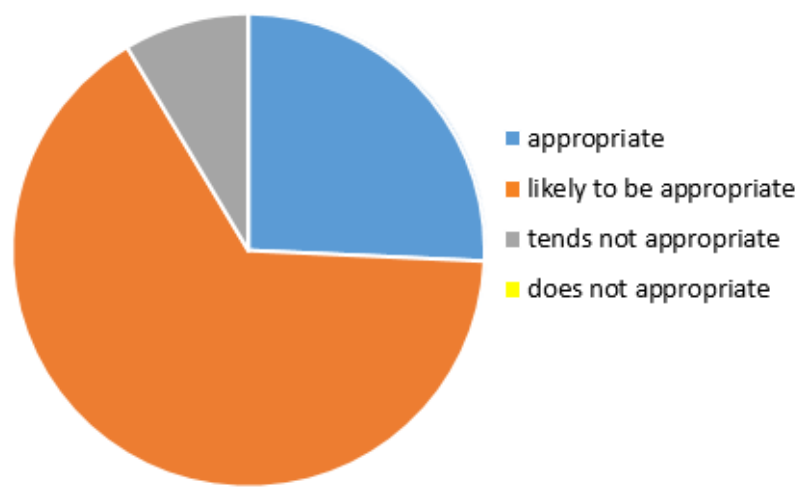

Figure 3. The Ability of Cooperation 
The ability to work together is essential competencies that must be owned by humans in nature as social beings. Referring to the opinion from the Hery Purnomo that one of the selfdevelopment that all teenagers must have due to their development is having a social skill to be able to adapt them to daily life. Social skills include the ability to communicate, establish rapport with others, respect yourself and others, to listen to opinions or complaints from other people, give or take criticism, acting according to the norms and rules, as well as skills in cooperation. Educational institutions have an important role in helping teens develop social skills-social skills [6].

By looking at the diagram depicted above, it is understood that the potential collaboration capabilities possessed by boarding school students tend to be higher than high school students. This is partly due to the presence of understanding of the concepts learned ukhuwah boarding school students from the asatidz (Muslim teachers).

Andre Widigar said that cooperation is the wish to cooperate with others in cooperative and became part of the group. Instead of working separately or side competing. Competence stresses the role of cooperation as members of the group, not as a leader. The group here in the sense of a broad group of individuals who completed a task or process. For steady cooperation entwined within a group of each member, so that it is able to solve problems that were faced, to note a few things that could support, among other things:

- $\quad$ Each party must be aware of and acknowledge the ability of each

- Each party shall cooperate must know and understand the problem at hand

- Each of the parties in cooperation needs to communicate

- Parties in cooperation need to be sensitive to the other party in terms of understanding the difficulties and shortcomings of others

- Although all parties should give accordance with ability, but in order that they can be empowered to succeed and give the results, there needs to be a setting, i.e., a steady coordination

- Openness to involve others

High school student

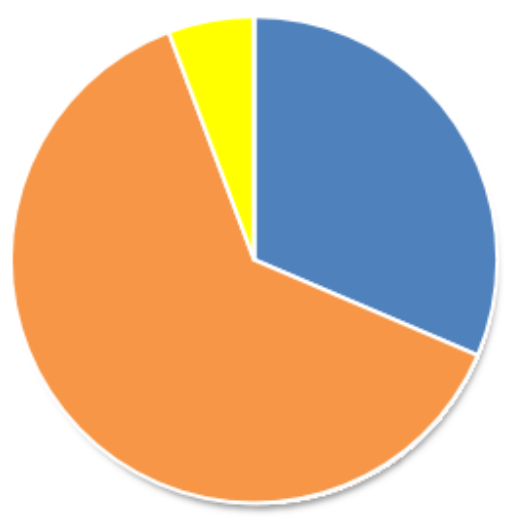

Islamic boarding school student

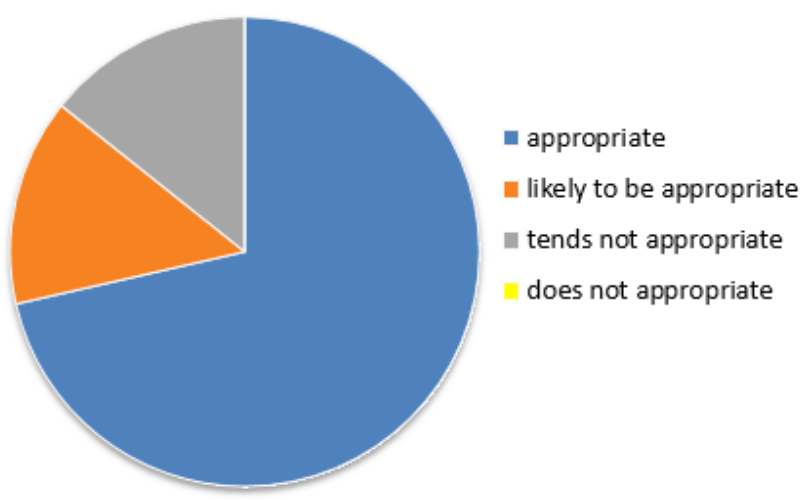

Figure 4. Positive Attitude and Enthusiasm

Next is the aspect that shows the positive attitude and enthusiasm, as part of the dimension of the mingling effectively. Enthusiasm is the attitude to do something without any coercion. 
Enthusiastic attitude will lead to thoughts, feelings, and actions as well as positive behavior. Enthusiastic attitude raises the motivation to do something the best, improve the quality of relationships with others, making individuals tend to be more open to ideas or new opportunities.

The tendency to demonstrate a positive attitude and enthusiasm shown by the high school students are more visible than that shown by boarding schools students. This data was obtained both quantitatively through questionnaires, nor the form of qualitative data obtained by researchers based observations.

One forms a positive and enthusiastic attitude, visible by the time pay attention to the reaction of high school students when they accept the researcher's presence among them. The high school students tend to be more straightforward in answering questions, without load, and confident. Whereas the different attitude has shown that boarding schools students more leads to maintain a good attitude and careful in answering questions, as well as when issuing their opinions. Thereby, one can say any kind of education gives effect either directly or indirectly to the character of educates students, regardless of the amount of influence on each student or students.

\section{Conclusions}

Based on the above explanation, it can be concluded that there are differences in the tendency of the characters in between the two objects of research with the extended respectively as a result of the kind of education system they are living, with the following description: a fun personal aspect, a positive attitude, and enthusiasm of high school students tend to be higher than the boarding school students. While the potential to communicate effectively-clearly-open to suggestions/a good listener, as well as the ability to work together in groups, the boarding school students is higher than high school students.

\section{References}

[1] J. V. Gilmore, “The Productive Personality," J. Educ., vol. 154, no. 1, pp. 5-39, Oct. 1971.

[2] T. Dale, Kinerja (Performance). Jakarta: Gramedia, 1989.

[3] J. W. Best, Metodologi Penelitian Pendidikan (The methodology of educational research). Surabaya: Usaha Nasional, 1982.

[4] Margono, Metodologi Penelitian Pendidikan. Jakarta: Rineka Cipta, 2004.

[5] G. W. Allport, The Nature of Prejudice. Oxford: Addison-Wesley, 1954.

[6] H. Purnomo, "Kemampuan Bekerjasama Dan Proses Pembiasannya Melalui Pembelajaran Fisika Sma Berbasis Empat Pilar Pendidikan," Universitas Negeri Semarang, 2008. 